\title{
Prevalence and Characterization of Salmonella Present during Veal Harvest
}

\author{
JOSEPH M. BOSILEVAC, ${ }^{*}$ SAMSON ZHILYAEV, ${ }^{2}$ RONG WANG, ${ }^{1}$ BRANDON E. LUEDTKE, ${ }^{3}$ TOMMY L. WHEELER, ${ }^{1}$ \\ AND MOHAMMAD KOOHMARAIE
}

${ }^{1}$ U.S. Department of Agriculture, Agricultural Research Service, U.S. Meat Animal Research Center, P.O. Box 166, State Spur 18D, Clay Center, Nebraska 68933 (ORCID: https://orcid.org/0000-0002-0258-6581 [J.M.B.]; https://orcid.org/0000-0003-1924-3275 [R.W.]; https://orcid.org/0000-0002-6571-9097 [T.L.W.]); ${ }^{2}$ Virginia Polytechnic Institute and State University, 1145 Perry Street, Blacksburg, Virginia 24061; ${ }^{3}$ University of Nebraska Kearney, 2401 11th Avenue, Kearney, Nebraska 68849 (ORCID: https://orcid.org/0000-0003-3349-3270 [B.E.L.]); and ${ }^{4}$ IEH Laboratories and Consulting Group, 15300 Bothell Way N.E., Lake Forest Park, Washington 98155, USA

MS 18-478: Received 3 October 2018/Accepted 31 December 2018/Published Online 15 April 2019

\begin{abstract}
Beef and veal products have been vehicles implicated in the transmission of Salmonella enterica, a gastroenteritis-causing bacteria. Recent regulatory samples collected from veal have indicated bob veal, or calves harvested within days of birth, have higher rates of Salmonella than samples collected from formula-fed veal, or calves raised 20 weeks on milk replacer formula before harvest. To investigate this problem, we collected samples from veal calf hides, preevisceration carcasses, and final carcasses at five veal processors that harvested bob or formula-fed veal or both. Prevalence and concentrations of Salmonella were determined, and then the isolates were characterized for serovar and antibiotic susceptibility. Salmonella was more prevalent $(P<0.05)$ among bob veal than formula-fed veal hides, preevisceration carcasses, and final carcass $(84.2$ versus $15.6 \%, 62.8$ versus $10.1 \%$, and 12.0 versus $0.4 \%$, respectively). Concentrations of Salmonella could be estimated by using regression order statistics on hides and preevisceration carcasses at two veal plants, with one harvesting bob veal and the other bob and formula-fed veal. The concentration of Salmonella on bob veal hides at the plants was $1.45 \pm 0.70$ and $2.04 \pm 1.00 \mathrm{log}$ $\mathrm{CFU} / 100 \mathrm{~cm}^{2}$, greater $(P<0.05)$ than on formula-fed veal hides, which was $1.10 \pm 1.51 \log \mathrm{CFU} / 100 \mathrm{~cm}^{2}$. Concentrations on carcasses, however, were very low. Seventeen Salmonella serovars were identified among 710 isolates. Salmonella serovars London, Cerro, and Muenster were most common to bob veal and made up 50.7, 18.7, and 6.3\% of the isolates, respectively, while serovar Montevideo (6.8\% of isolates) was most common to formula-fed veal. Although bob veal had increased prevalence and concentrations of Salmonella, one group of formula-fed veal was found to harbor human disease-related antibiotic-resistant Salmonella serovars Heidelberg and the monophasic variant of Typhimurium (1,4,[5],12:i:-). Veal processors have made changes to improve the safety of veal, but further efforts are necessary from both bob and formula-fed veal to address Salmonella.
\end{abstract}

Key words: Processing; Salmonella; Veal

Salmonella enterica is estimated to cause 1.2 million cases of gastroenteritis, 23,000 hospitalizations, and 450 deaths each year in the United States (39). Cattle are among the multitude of Salmonella reservoirs; thus, ground beef has been implicated as a mode of transmission in foodborne outbreaks $(13,32)$. The implementation of hazard analysis and critical control point plans at large and small beef processors has decreased Salmonella in ground beef by $30 \%$ (7.5 to 5.8\%) (19). Since the Food Safety and Inspection Service (FSIS) published its approach to control the entry of Salmonella into the meat supply, the monitoring and regulation of Salmonella has become more stringent (43), yet the prevalence of antimicrobial-resistant strains is of constant concern.

\footnotetext{
* Author for correspondence. Tel: 402-762-4225; Fax: 402-762-4149; E-mail: mick.bosilevac@ars.usda.gov.
}

Surveillance data from the National Antimicrobial Resistance Monitoring System, which tracks antimicrobial resistance (AMR) in bacteria isolated from humans, animals, and foods, has shown a continued increase in the proportion of AMR in Salmonella (14). This is a concern because AMR strains may cause more severe and prolonged disease than the antimicrobial susceptible strains $(42,48)$. AMR in Salmonella is not only a public health concern but also a food safety concern, as a 2002 outbreak linked to AMR in Salmonella enterica serovar Newport in ground beef caused 47 illnesses, 17 hospitalizations, and one death (12).

Veal is the meat of young cattle or calves, mostly of dairy cattle breeds, of which approximately 45,000 metric tons are consumed in the United States each year. Two types of veal are generally harvested in the United States, bob veal (calves sold and harvested within the first few days of 
life), and formula-fed veal (calves raised on a milk replacer diet until harvested at about 20 weeks of age (44)). Since June 2012, FSIS has increased its regulatory attention on veal due to a higher percentage of non-O157 Shiga toxinproducing Escherichia coli-positive samples collected from veal trimmings than from products produced from other classes of cattle. This increased attention has revealed that although veal carcasses have a lower overall prevalence of Salmonella compared with beef carcasses (47), the portion that is bob veal relative to formula-fed veal is more contaminated with Salmonella (29).

Although Salmonella has long been identified as a problem in veal $(30,36,41,51)$, its prevalence during the various steps of modern U.S. veal processing has not been examined, and the biological rationale for the higher positive rate in bob veal relative to formula-fed veal and beef is unclear. Therefore, the objectives of this study were to (i) assess the rates and concentrations of Salmonella present on veal calf hides, veal preevisceration carcasses, and final chilled veal carcasses and (ii) characterize the serovars and antibiotic susceptibility of any Salmonella identified. To accomplish this goal, samples collected at five veal processors, which harvested formula-fed veal or bob veal or both, were examined for prevalence and characterization of Salmonella.

\section{MATERIALS AND METHODS}

Design. Five veal processors that harvested formula-fed or bob veal or both were visited once (two of the processors) or twice (three of the processors), and samples were collected from hides, preevisceration carcasses, and final carcasses to determine the prevalence and concentration of Salmonella at each plant for each sample and veal type. Salmonella isolates were characterized for serovar and antibiotic sensitivity.

Sample collection and processing. Hide, preevisceration carcass, and final carcass samples were collected as previously described (8) by using buffered peptone water-moistened (BD, Sparks, MD) Speci-Sponges in Whirl-Pak bags (Nasco, Fort Atkinson, WI). Hide samples were obtained by swabbing an area $\left(600 \mathrm{~cm}^{2}\right)$ over the brisket-plate region after stunning and exsanguination. Preevisceration carcass samples were collected as soon as possible after complete removal of the hide and final carcass samples were collected from chilled or chilling carcasses as they entered the cooler. The carcass samples were collected from the brisket-plate and hock-round areas of one side of each carcass from an area of $6,000 \pm 100 \mathrm{~cm}^{2}$ for formula-fed veal carcasses and 2,000 $\pm 200 \mathrm{~cm}^{2}$ for bob veal carcasses. Carcass samples were not directly matched to one another or to hide samples, but all samples were collected during one shift at each processor. All sponge samples were shipped to the laboratory in insulated coolers via overnight courier. On receipt in the laboratory, each sample was hand massaged thoroughly in the bag, and an aliquot $(1.0 \mathrm{~mL}$ from hide samples and $4.0 \mathrm{~mL}$ from preevisceration and final carcasses samples) removed for enumeration of Salmonella as described in the following. After the aliquots for enumeration were removed from each sample, $80 \mathrm{~mL}$ of tryptic soy broth (TSB; BD) was added to each sample for nonselective enrichment to determine the prevalence of Salmonella as described in the following.
Enumeration of Salmonella. To enumerate the amount of Salmonella on hides, a $50-\mu \mathrm{L}$ portion of each sample was spiral plated onto one xylose lysine desoxycholate medium (Oxoid, Remel, Lenexa, KS) plate containing $4.6 \mathrm{~mL} / \mathrm{L}$ Tergitol, $15 \mathrm{mg} / \mathrm{L}$ novobiocin, and $5 \mathrm{mg} / \mathrm{L}$ cefsulodin $\left(\mathrm{XLD}_{\mathrm{tnc}}\right.$; MilliporeSigma, $\mathrm{St}$. Louis, MO) (9). Plates were incubated at $37^{\circ} \mathrm{C}$ for 18 to $22 \mathrm{~h}$, and presumptive colonies were counted and confirmed as Salmonella by PCR amplification of the Salmonella-specific invA target (50). To enumerate the amount of Salmonella on preevisceration carcasses, a 1-mL portion of each sample was dispensed onto Petrifilm EB (3M Microbiology, St. Paul, MN) for the growth of Enterobacteriaceae. The Petrifilm was incubated at $37^{\circ} \mathrm{C}$ for 15 to $20 \mathrm{~h}$ and then held at $4^{\circ} \mathrm{C}$ (approximately $48 \mathrm{~h}$ ) until the results of Salmonella isolation were complete. Then, all carcass samples found culture positive for Salmonella had their corresponding Petrifilm plates replica plated onto $\mathrm{XLD}_{\mathrm{tnc}}$, as described previously (10). The $\mathrm{XLD}_{\text {tnc }}$ plates were incubated, and suspect colonies counted and confirmed as described previously. When present, up to 10 colonies were selected for confirmation. If any suspect colonies did not confirm to be Salmonella, the concentration was calculated by multiplying the number of suspect colonies by the number confirmed divided by the number tested.

Determination of Salmonella prevalence. After $80 \mathrm{~mL}$ of TSB (see earlier text) was added, each sponge sample was enriched as previously described (8). Then, a 1-mL aliquot of the TSB enrichment was removed from each sample for immunomagnetic concentration, selective enrichment in RappaportVassiliadis soya broth (Oxoid), and streaked for isolation onto an $\mathrm{XLD}_{\mathrm{tnc}}$ plate as previously described (11). Plates were viewed for presumptive Salmonella (black colonies), and then two wellisolated presumptive colonies per plate were arbitrarily selected and picked with a sterile loop to a 96-well block of TSB $(0.5 \mathrm{~mL}$ per well). The 96-well TSB blocks were incubated at $37^{\circ} \mathrm{C}$ overnight (15 to $22 \mathrm{~h}$ ), and then $2 \mu \mathrm{L}$ was removed from each well and the isolate confirmed to be Salmonella by using PCR as described previously (50).

Serotyping of Salmonella isolates. One confirmed Salmonella isolate per positive enumeration or prevalence sample was streaked for isolation onto tryptic soy agar (TSA; BD) and incubated at $37^{\circ} \mathrm{C}$ for 18 to $20 \mathrm{~h}$, and then the serovar was determined by using the molecular methods as previously described $(20,26,27)$. Resulting serovars were confirmed by using slide agglutination ( $\mathrm{O}$ typing) and tube agglutination (flagellar H-typing) methods, with commercial antisera (Difco, BD Diagnostic Systems, Sparks, MD), following manufacturer's guidelines. When molecular methods were not confirmed or when molecular methods did not provide a serovar for an isolate, Wellcolex Color Salmonella agglutination (Remel) and traditional slide agglutination $\mathrm{O}$ grouping and tube agglutination flagellar $\mathrm{H}$ typing were performed and considered as the correct serovar.

Susceptibility screening. Each isolate of Salmonella was inoculated into a well of a 96-well block containing TSB. This block was incubated overnight at $37^{\circ} \mathrm{C}$, and then $10 \mu \mathrm{L}$ from each well was transferred to a second 96-well block containing $1 \mathrm{~mL}$ of buffered peptone water in each well. The diluted $(1: 100)$ Salmonella strains were screened for resistance to antibiotics by using a 96-pin Boekel microplate replicator (Boekel Scientific, Feasterville, PA) to inoculate three $150-\mathrm{mm}$ TSA plates supplemented with either $32 \mathrm{mg} / \mathrm{L}$ tetracycline (Tet), $32 \mathrm{mg} / \mathrm{L}$ nalidixic acid ( $\mathrm{Nal}$ ), or $2 \mathrm{mg} / \mathrm{L}$ cefotaxime (Ctx), and one nonsupplemented TSA plate that served as a growth control. Inoculated plates were 
TABLE 1. Prevalence of Salmonella on bob and formula-fed veal hides and carcasses at five processors over two sample collections

\begin{tabular}{|c|c|c|c|c|c|c|}
\hline \multirow[b]{3}{*}{ Plant } & \multirow[b]{3}{*}{ Sampling $^{a}$} & \multirow[b]{3}{*}{ Type $^{b}$} & \multirow[b]{3}{*}{$n$} & \multicolumn{3}{|c|}{$\%$ Salmonella prevalence ${ }^{c}$} \\
\hline & & & & \multirow[b]{2}{*}{ Hide } & \multicolumn{2}{|c|}{ Carcass: } \\
\hline & & & & & Preevisceration & Final \\
\hline A & Initial & Formula-fed & 90 & $3.3 \mathrm{D}^{d}$ & $0.0 \mathrm{D}$ & $0.0 \mathrm{C}$ \\
\hline $\mathrm{B}$ & Initial & Bob & 95 & $100.0 \mathrm{~A}$ & 70.5 в & $7.4 \mathrm{~B}$ \\
\hline $\mathrm{B}$ & Follow-up & Bob & 95 & 52.6 в & $21.1 \mathrm{C}$ & $7.4 \mathrm{~B}$ \\
\hline $\mathrm{C}$ & Initial & Formula-fed & 95 & $0.0 \mathrm{D}$ & $0.0 \mathrm{D}$ & $0.0 \mathrm{C}$ \\
\hline $\mathrm{C}$ & Follow-up & Formula-fed & 95 & $26.3 \mathrm{C}$ & $3.2 \mathrm{D}$ & $0.0 \mathrm{C}$ \\
\hline $\mathrm{D}$ & Initial & Formula-fed & 95 & $1.1 \mathrm{D}$ & $0.0 \mathrm{D}$ & $0.0 \mathrm{C}$ \\
\hline $\mathrm{D}$ & Follow-up & Formula-fed & 95 & $4.2 \mathrm{D}$ & $1.1 \mathrm{D}$ & $0.0 \mathrm{C}$ \\
\hline $\mathrm{E}$ & Initial & Bob & 95 & $100.0 \mathrm{~A}$ & $96.8 \mathrm{~A}$ & $21.1 \mathrm{~A}$ \\
\hline $\mathrm{E}$ & Initial & Formula-fed & 48 & $100.0 \mathrm{~A}$ & $100.0 \mathrm{~A}$ & $4.2 \mathrm{~B} \mathrm{C}$ \\
\hline A & & & 90 & $3.3 \mathrm{o}$ & $0.0 \mathrm{~N}$ & $0.0 \mathrm{~N}$ \\
\hline $\mathrm{B}$ & & & 190 & $76.3 \mathrm{M}$ & $45.8 \mathrm{M}$ & $7.4 \mathrm{M}$ \\
\hline $\mathrm{C}$ & & & 190 & $13.2 \mathrm{~N}$ & $1.6 \mathrm{~N}$ & $0.0 \mathrm{~N}$ \\
\hline $\mathrm{D}$ & & & 190 & $2.7 \mathrm{o}$ & $0.6 \mathrm{~N}$ & $0.0 \mathrm{~N}$ \\
\hline \multirow[t]{5}{*}{$\mathrm{E}$} & & & 143 & $100.0 \mathrm{~L}$ & $97.9 \mathrm{~L}$ & $15.4 \mathrm{~L}$ \\
\hline & Initial & & 285 & $33.7 \mathrm{Q}$ & $23.5 \mathrm{Q}$ & $2.5 \mathrm{Q}$ \\
\hline & Follow-up & & 285 & $27.7 \mathrm{Q}$ & $8.5 \mathrm{R}$ & $2.5 \mathrm{Q}$ \\
\hline & & Formula-fed & 518 & $15.6 \mathrm{Y}$ & $10.1 \mathrm{Y}$ & $0.4 \mathrm{Y}$ \\
\hline & & Bob & 285 & $84.2 \times$ & $62.8 \times$ & $12.0 \mathrm{x}$ \\
\hline All combined & & & 803 & 39.9 & 28.5 & 4.5 \\
\hline
\end{tabular}

${ }^{a}$ There were two sample collections performed at three of the plants approximately 12 months later.

${ }^{b}$ Type of veal: bob, calves younger than 2 weeks old; formula-fed, calves raised on milk replacer formula for 20 to 22 weeks.

${ }^{c}$ Values represent the percentage of samples found to be positive for Salmonella by culture isolation. Preevisceration, carcass after hide was fully removed and before interventions were applied.

${ }^{d}$ Within each section and within a column, values followed by the same letter (A through $\mathrm{D}, \mathrm{L}$ though $\mathrm{O}, \mathrm{Q}$ and $\mathrm{R}$, and $\mathrm{X}$ and $\mathrm{Y}$ ) are not different $(P>0.05)$.

incubated at $37^{\circ} \mathrm{C}$ for $16 \mathrm{~h}$ and then viewed for growth. Isolates were considered resistant to the selected antibiotic if growth on antibiotic-containing agar was visually the same as growth on control agar lacking antibiotics. If small microcolonies were present, the growth was interpreted as sensitive to the antibiotic.

Statistical analysis. Analysis of variance of Salmonella prevalence and mean concentrations of Salmonella (log transformed) for each sample type by plant and veal type (formula-fed and bob) was performed by using GraphPad Prism Software (GraphPad Software, La Jolla, CA). Specifically, the nonparametric data were analyzed by using Kruskal-Wallis one-way analysis of variance by ranks with Dunn's multiple comparison posttest, with $P<0.05$ being significant. For the concentration of Salmonella, all culture-positive samples that were nonenumerable were assigned an arbitrary value of one-half the level of detection (LOD). Then, the "regression on order statistics" (ROS) method for censored analysis was used to calculate summary statistics (e.g., log mean and standard deviation). This approach uses the information that is available in nonenumerable but positive data by assuming microbial concentrations fit a parametric distribution (log normal). Specifically, a linear regression is used to fit the normal quantiles of the censored and noncensored log data to obtain a more accurate mean and standard deviation than substitution or omission (25).

\section{RESULTS AND DISCUSSION}

Prevalence of Salmonella contamination. FSIS has maintained increased attention to veal processing and products since 2012 when veal samples were observed to have a higher percentage of non-O157 Shiga toxinproducing $E$. coli than beef samples $(44,45)$. This scrutiny later lead to observations of Salmonella being disproportionately higher in bob veal compared with other forms of veal $(29,46)$. Therefore, during other studies of veal processing to assess efficacy of sanitary dressing procedures at five veal processors (8), we examined the prevalence, concentration, and types of Salmonella on hides, preevisceration carcasses, and final carcasses.

As hide is the general source of E. coli and Salmonella contamination in beef processing $(5,7,37)$, we examined veal hides. Overall, 39.9\% of veal hides were positive for Salmonella (Table 1). This varied significantly by plant, sample collection trip, and veal type. Plants that harvested bob veal had higher hide prevalence (145 of 190, 76.3\%, and 143 of $143,100 \%$ ) than those that exclusively harvested formula-fed veal (5 of 190, 2.7\%; 3 of 90, 3.3\%, and 25 of 190, 13.2\%). However, follow-up hide samples showed both veal types could present with a different $(P<0.05)$ 
prevalence of Salmonella on their hides at any given time. All the initial bob veal hide samples collected at plant B were positive (95 of 95, 100\%), while 50 (52.6\%) of 95 follow-up samples were positive. Conversely, no Salmonella was found on formula-fed veal hides during the initial collection at plant C ( 0 of 95$)$, but $25(26.3 \%)$ of 95 of hides were Salmonella positive during the follow-up sample collection. Overall, the hide prevalence of Salmonella between the initial and follow-up samples at all plants combined was lower but not significantly different $(P>$ 0.05). Although the difference in hide Salmonella between all bob and formula-fed veal was significant $(P<0.05)$, there was no significant difference between veal types at plant $\mathrm{E}(P>0.05)$, where both types of veal were harvested. At plant E, all hides of bob (95 of 95) and formula-fed (48 of 48) veal were Salmonella positive, possibly as a result of cross-contamination in lairage environments (1).

The prevalence of Salmonella on preevisceration carcasses followed what was observed for hides. The highest prevalence of Salmonella on preevisceration carcasses was at plants B and E, which harvested bob veal and where $87(45.8 \%)$ of 190 and $140(97.9 \%)$ of 143 of preevisceration carcasses were Salmonella positive (Table 1). Although the initial and follow-up sample collections showed no difference in hide Salmonella prevalence, there was a significant difference $(P<0.05)$ in preevisceration carcass prevalence at $67(23.5 \%)$ of 285 versus $24(8.5 \%)$ of 285. Our follow-up samples were collected, in part, to examine changes made at plants B, C, and D in sanitary dressing procedures following the initial sample collection (8). Indeed, the rates of hide-to-carcass transfer (HTCT) as calculated by the ratio of preevisceration carcass prevalence to hide prevalence of Salmonella (11) was 0.697 initially and 0.307 after changes to dressing procedures were made (data not shown). This reduction in HTCT was primarily impacted by changes in the contamination of bob veal carcasses at plant B.

The prevalence of Salmonella on finished veal carcasses was only observed at plants B and E, where bob veal was harvested and where preevisceration carcass contamination was increased (Table 1). Overall, 34 (12.0\%) of 285 bob veal final carcasses were Salmonella positive, while only $2(0.4 \%)$ of 518 formula-fed veal final carcasses were. Despite improvements to dressing procedures that resulted in lower preevisceration carcass Salmonella at plant B, the final carcasses were unchanged in Salmonella prevalence between the two sample collections. The reason for this is not clear. We suspect that postevisceration processing interventions were less effective or inconsistently delivered when applied to smaller bob veal carcasses. This may be why at plant E, where nearly all preevisceration carcasses of both bob and formula-fed veal were contaminated with Salmonella, about three times as many bob veal final carcasses were Salmonella positive after traveling the same processing line as compared with formula-fed veal carcasses. Another likely cause could be variability in the slaughter facilities. For example, effectiveness may have increased overall, but sampling during the follow-up happened during an unusually high contamination period or during poor sanitation conditions that day. Incoming bob veal that had a higher estimated concentration of Salmonella present but with much more variability is discussed later. Because there was so little Salmonella detected on final carcasses, variability in sample collections is just as likely as other hypothetical causes.

Salmonella was found at four of the five veal plants visited; however, its prevalence at two of the plants (A and D) was negligible compared with the $100 \%$ prevalence observed on hides at plants B and E. Again, this observation supports the findings of FSIS in that the increased prevalence of Salmonella is associated with bob veal calves. The prevalence of Salmonella on the hides of cull cattle and cull cows has been reported to similarly range from 70 to $100 \%(4,11)$. The HTCT of Salmonella was significant with the preevisceration carcass prevalence of Salmonella at 45.8 and $97.9 \%$ for plants B and E, respectively. When hide Salmonella prevalence of $100 \%$ was previously reported for small processing plants, preevisceration carcass prevalence of Salmonella was observed to vary by plant from $93.7 \%$ to 80.4 and $72.6 \%$ (4). At plants A and D, where hide Salmonella prevalence was 3.3 and $2.7 \%$, only one preevisceration carcass was found to be contaminated by Salmonella.

Concentrations of Salmonella contamination. In addition to measuring the prevalence of Salmonella contaminating veal at the five processors, we also determined the load of Salmonella present through enumeration (Table 2). Measurable concentrations of Salmonella were only found on hides and preevisceration carcasses at plants $\mathrm{B}$ and $\mathrm{E}$, corresponding to the plants that harvested bob veal. Using ROS (25), the mean concentration of Salmonella on hides was estimated to be 1.10 to 2.04 $\log \mathrm{CFU} / 100 \mathrm{~cm}^{2}$, while the mean concentration on preevisceration carcasses was highly variable, with estimates ranging from -5.25 to $-1.51 \log \mathrm{CFU} / 100 \mathrm{~cm}^{2}$.

We used ROS to estimate the concentrations of Salmonella on the hides and carcasses because values determined by ROS are more accurate in situations with results such as ours (25). Generally, when calculating mean concentrations, there is a problem when considering samples that are culture positive but nonenumerable, that is, at a concentration less than the LOD of the enumeration method. Our culture method has been validated to detect 1 to $3 \mathrm{CFU}$ in a sample; thus, the LOD of culture was orders of magnitude lower than the enumeration method. For example, a hide sample could have been culture positive if 1 CFU of Salmonella were present, whereas approximately 20,000 CFU were required present to reach the LOD of the enumeration method. A common practice to address this situation in data analysis is to replace the unknown concentrations with a value that is half $(50 \%)$ of the LOD; however, that results in an artificially high estimate of the concentration and masks the variability present in the data (25). By using ROS, instead of Kaplan-Meier statistics, we could examine events when there were less than $50 \%$ enumerated values, as ROS is more robust and provides 
TABLE 2. Concentrations of Salmonella on bob and formula-fed veal hides and preevisceration carcasses at five processors over two sample collections ${ }^{a}$

\begin{tabular}{|c|c|c|c|c|c|c|c|c|}
\hline Plant & Sample $^{b}$ & Type $^{c}$ & $n$ & $\begin{array}{c}\text { No. } \\
\text { positive }\end{array}$ & $\begin{array}{c}\text { No. } \\
\text { enumerable }\end{array}$ & Mean $^{d}$ & $\mathrm{SD}^{d}$ & Range $^{e}$ \\
\hline \multicolumn{9}{|l|}{ Hide } \\
\hline A & Initial & Formula-fed & 90 & 3 & 0 & & & -0.78 to 1.82 \\
\hline $\mathrm{B}$ & Initial & Bob & 95 & 95 & 39 & 1.45 & 0.70 & -0.78 to 3.60 \\
\hline $\mathrm{B}$ & Follow-up & Bob & 95 & 49 & 1 & & & -0.78 to 1.82 \\
\hline $\mathrm{C}$ & Initial & Formula-fed & 95 & 0 & & & & \\
\hline $\mathrm{C}$ & Follow-up & Formula-fed & 95 & 25 & 0 & & & -0.78 to 1.82 \\
\hline $\mathrm{D}$ & Initial & Formula-fed & 95 & 1 & 0 & & & -0.78 to 1.82 \\
\hline $\mathrm{D}$ & Follow-up & Formula-fed & 95 & 4 & 0 & & & -0.78 to 1.82 \\
\hline $\mathrm{E}$ & Initial & Bob & 95 & 95 & 60 & 2.04 & 1.00 & -0.78 to 5.39 \\
\hline $\mathrm{E}$ & Initial & Formula-fed & 48 & 48 & 8 & 1.10 & 1.51 & -0.78 to 4.00 \\
\hline \multicolumn{9}{|c|}{ Preevisceration carcass } \\
\hline A & Initial & Formula-fed & 90 & 0 & & & & \\
\hline $\mathrm{B}$ & Initial & Bob & 95 & 66 & 4 & -5.25 & 2.74 & -0.88 to 1.62 \\
\hline $\mathrm{B}$ & Follow-up & Bob & 95 & 20 & 3 & -1.51 & 0.72 & -0.88 to 0.30 \\
\hline $\mathrm{C}$ & Initial & Formula-fed & 95 & 0 & & & & \\
\hline $\mathrm{C}$ & Follow-up & Formula-fed & 95 & 3 & 0 & & & -1.48 to -0.48 \\
\hline $\mathrm{D}$ & Initial & Formula-fed & 95 & 0 & & & & \\
\hline $\mathrm{D}$ & Follow-up & Formula-fed & 95 & 1 & 0 & & & -1.48 to -0.48 \\
\hline $\mathrm{E}$ & Initial & Bob & 95 & 91 & 7 & -4.75 & 2.81 & -0.88 to 2.15 \\
\hline $\mathrm{E}$ & Initial & Formula-fed & 48 & 48 & 3 & -2.04 & 0.92 & -1.48 to 0.00 \\
\hline
\end{tabular}

${ }^{a}$ Only Salmonella concentrations from hides and preevisceration carcasses presented as final carcasses lacked any enumerable amounts of Salmonella to allow calculation.

${ }^{b}$ There were two sample collections performed at three of the plants approximately 12 months later.

${ }^{c}$ Type of veal: bob, calves younger than 2 weeks old; formula-fed, calves raised on milk replacer formula for 20 to 22 weeks.

${ }^{d}$ Means and standard deviations (SD) calculated by ROS method of censored data.

${ }^{e}$ Range provides the concentrations of Salmonella used for calculations. Low value represents 1 CFU of Salmonella in sample to provide culture positive; high value represents the enumeration level of detection (LOD) or greatest measured concentration. The LOD for hides was $1.82 \log \mathrm{CFU} / 100 \mathrm{~cm}^{2}$, LOD of bob veal carcasses was $0.00 \log \mathrm{CFU} / 100 \mathrm{~cm}^{2}$, and LOD of formula-fed veal carcasses was -0.48 $\log \mathrm{CFU} / 100 \mathrm{~cm}^{2}$.

good estimates down to about $20 \%$ enumerated values (25). Our preevisceration carcass enumeration results, however, were still out of the recommend range, even for ROS, so calculated mean concentrations should not be taken directly, but rather qualitatively. As a whole, the ROS estimated concentrations of Salmonella on preevisceration carcasses support the premise that the sanitary dressing practices and antimicrobial interventions were preventing and reducing HTCT, but there remains intermittent clusters of contamination.

When examining the number of hides that were enumerable, $28 \%(39+1$ of $95+49$ [40 of 144]) and $63 \%$ (60 of 95) bob veal hides at plants B and E, respectively (Table 2), had Salmonella present at a concentration greater than our limit of detection (LOD = $1.8 \log \mathrm{CFU} / 100 \mathrm{~cm}^{2}$ ). At plant E, the difference between bob veal hides and formula-fed veal hides was significantly different $(P<0.05)$ for the number that were enumerable, as well as the concentration of Salmonella present. Significant differences $(P<0.05)$ in the number of enumerable hides at plant $\mathrm{B}$ were also seen between the two collection times at that plant. Thirty-nine (41\%) of 95 bob veal hides were enumerable at plant B during the initial sample collection, while only $1(2 \%)$ of 49 of the culturepositive bob veal hides on the second sample collection were enumerable. This veal processor had made changes to their processes between the two sample collections that included optimizing a hide-directed intervention (49), and this may have contributed to the decreased hide Salmonella concentration measured on the follow-up sampling.

Only 14 (8\%) of 177 bob veal preevisceration carcasses had enumerable Salmonella (Table 2); however, the difference between the two sample collections at plant $\mathrm{B}$ was significantly different $(P<0.05)$ in this regard with 4 $(6 \%)$ of 66 initially and 3 (15\%) of 20 on follow-up. The ROS mean concentration on the carcasses was different as well between the two sampling periods, and although the number of Salmonella prevalence positive carcasses was reduced in the second sample collection, the proportion that was enumerable was greater. Due to differences in carcass sizes, the surface area sampled was different between bob and formula-fed veal carcasses such that the LOD of Salmonella on bob veal carcasses was $0.0 \log$ CFU/100 $\mathrm{cm}^{2}$, while the LOD for formula-fed veal carcasses was $-0.48 \log \mathrm{CFU} / 100 \mathrm{~cm}^{2}$. If it had not been for the increased sample area and lower LOD, enumerable formula-fed veal carcasses would likely not have been identified. No final veal carcasses had enumerable amounts of Salmonella present. 
In comparison to other studies using similar enumeration methods, 9.4 to $21.3 \%$ of cull cattle hides were found to be enumerable for Salmonella during different seasons of the year, and the observed mean load was 1.9 to $2.2 \mathrm{log}$ $\mathrm{CFU} / 100 \mathrm{~cm}^{2}$, with individual measurements ranging from 1.6 to $4.5 \log \mathrm{CFU} / 100 \mathrm{~cm}^{2}$ (11). In a study of seven small processing plants, $36.6 \%$ of hides were found enumerable for Salmonella, with a range of 1.6 to $5.6 \log$ CFU/100 $\mathrm{cm}^{2}$ (4). For preevisceration cull cattle carcasses, 5.1 and $13.0 \%$ were found enumerable at concentrations ranging from -0.3 to $2.7 \log \mathrm{CFU} / 100 \mathrm{~cm}^{2}$ (11). Fourteen percent of Salmonella-positive preevisceration carcasses at seven small processors were only enumerable at concentrations ranging from -0.3 to $2.9 \log C F U / 100 \mathrm{~cm}^{2}$ (4). These previous studies determined mean concentrations of Salmonella by using only the enumerable sample values or censored data, whereas ROS was used here to provide a more accurate estimate of Salmonella concentrations on hides and carcasses. With the exception of the rates of enumerable Salmonella on bob veal hides being greater, the rate and the concentrations of enumerable Salmonella on preevisceration beef carcasses are similar to those of bob veal. Information on Salmonella prevalence and concentrations on finished veal carcasses is limited. In their beef and veal baseline survey report (46), FSIS found $15 \%$ of Salmonella-positive prechill veal carcasses enumerable at a mean concentration of $0.28 \log \mathrm{CFU} / 100 \mathrm{~cm}^{2}$, while $12 \%$ of prechill beef carcasses were enumerable at a mean concentration of $0.19 \log \mathrm{CFU} / 100 \mathrm{~cm}^{2}$. These concentrations were determined by using a most-probable-number (MPN) method (46), and direct comparisons to our values should be made with caution as injured cells can more easily recover and grow for detection in the MPN method compared with the direct plating assay (33).

These results also are consistent with those of Arthur et al. (2), indicating lower hide concentrations of a pathogen reduces the rate of HTCT. Veal processing is more challenging than beef processing due to the differences in the hides that must be removed during processing (49). Hide removal is the primary contributor to carcass contamination in beef processing $(5,7,37)$. Thus, with similar concentrations on hides, it is likely that the hide removal process from bob veal is responsible for contamination of bob veal carcasses, as illustrated in the data from plant E. Further, bob veal carcasses are much smaller than formula-fed veal carcasses. During our study, when bob veal carcasses were observed through processing, the carcasses shifted and changed position by swinging and swaying during hide removal and while encountering spray interventions. This may have caused more HTCT and hindered the efficacy of the carcass-directed interventions.

FSIS has reported in their beef and veal baseline survey report (46) that veal carcasses have a lower prevalence of Salmonella than beef carcasses and that the majority of Salmonella-contaminated veal carcasses are bob veal as opposed to formula-fed veal (29). Bob veal calves are only days old at harvest, and these young nonruminating calves harvested for veal are more easily colonized by Salmonella. Young animals are frequently colonized and are most likely to experience salmonellosis within 2 to 4 weeks of age (28), evidenced by Salmonella outbreaks in young calves and calf ranches that can lead to high amounts of Salmonella present during veal processing (34). Colonization can occur through exposure to asymptomatic carriers, such as adult cattle infected by Salmonella but showing no clinical signs of infection (23). Alternately, evidence has been reported that neonatal calves can acquire Salmonella through vertical transmission and already be infected at birth $(23,24)$. The lower rates of Salmonella in formula-fed veal is likely related to their rearing in barns and individual or lowdensity pens. Salmonella on the hide of a calf may not survive for long periods similar to E. coli O157:H7 (3) such that by 20 to 22 weeks of age, any Salmonella present no longer persists among the animals.

Characterization of Salmonella serovars. From each positive enumeration and prevalence sample, one Salmonella isolate was selected to identify its serovar (Table 3) and screened for resistance to $\mathrm{Ctx}$, Nal, and Tet. This resulted in 710 total isolates, with 125 from enumeration and 585 from prevalence. Because of the greater prevalence and concentrations of Salmonella in bob veal relative to formula-fed veal, there were 561 bob veal isolates and 149 formula-fed veal isolates. In addition, plant $\mathrm{E}$ accounted for 109 of the formula-fed veal isolates. As mentioned earlier, many of these formula-fed veal isolates at plant $\mathrm{E}$ may arguably be considered the result of cross-contamination from bob veal calves in the lairage pens, as the bob veal were processed before the formula-fed veal.

Seventeen different Salmonella serovars were identified (Table 3), with the most common serovar identified as Salmonella London, which accounted for 360 (50.7\%) of 710 of all the Salmonella isolates. This serovar was only found at plants $\mathrm{B}$ and $\mathrm{E}$ and has not been reported to be commonly isolated from beef or cattle in the United States $(4,6,9,11)$. Human infections by Salmonella London have been infrequently reported by the Centers for Disease Control and Prevention (15); however, it was associated with a Korean outbreak in 2000 traced to infant formula (31, 38). The next most common serovars were Salmonella Cerro (133 of $710,18.7 \%$ ), Montevideo (48 of $710,6.8 \%$ ), Muenster (45 of 710,6.3\%), and Agona (30 of 710, 4.2\%), which collectively accounted for an additional $36 \%$ of the isolates. These four serovars are commonly identified in beef products and cattle $(4,6,9,11)$, and Salmonella Montevideo and Agona are among the 20 most prevalent serovars reported by the Centers for Disease Control and Prevention (15). In most cases, the serovar of Salmonella isolated from a final carcass at a plant was also identified on preevisceration carcasses at that plant, and, likewise, a serovar of Salmonella isolated from a preevisceration carcass was also identified on hides at that plant.

When a serovar was observed more than once, it was seen at plants B and E (Table 3), where most of the isolates were found in the first place. The Salmonella serovars identified in the follow-up samples at plants B, C, and D were often different from those found during the initial sample collection, showing that the Salmonella was highly 
TABLE 3. Salmonella serovar distribution of isolates from enumeration and prevalence positive samples of hides, preevisceration carcasses, and final carcasses collected from bob and formula-fed veal calves at five processors during two sample collections ${ }^{a}$

\begin{tabular}{|c|c|c|c|c|c|c|c|c|c|c|c|c|c|c|c|c|}
\hline \multirow[b]{2}{*}{ Salmonella serovar } & \multicolumn{8}{|c|}{ Plant and collection trip observed ${ }^{b}$} & \multicolumn{4}{|c|}{ Bob veal $^{c}$} & \multicolumn{4}{|c|}{ Formula-fed veal $^{d}$} \\
\hline & A1 & B1 & B2 & $\mathrm{C} 1$ & $\mathrm{C} 2$ & D1 & D2 & E1 & $n$ & Hide & Pre & Final & $n$ & Hide & Pre & Final \\
\hline Agona $(n=30)$ & + & + & & & & & & + & 16 & 7 & 9 & 0 & 14 & 9 & 5 & 0 \\
\hline Altona $(n=2)$ & & & & & & & & + & 2 & 0 & 2 & 0 & 0 & 0 & 0 & 0 \\
\hline Amager $(n=1)$ & & & + & & & & & & 1 & 1 & 0 & 0 & 0 & 0 & 0 & 0 \\
\hline Anatum $(n=13)$ & & & & & & & & + & 10 & 8 & 2 & 0 & 3 & 3 & 0 & 0 \\
\hline Cerro $(n=133)$ & & + & + & & & & & + & 132 & 84 & 34 & 14 & 1 & 0 & 1 & 0 \\
\hline Dublin $(n=21)$ & & & + & & & & & & 1 & 1 & 0 & 0 & 0 & 0 & 0 & 0 \\
\hline Give $(n=3)$ & & + & & & & & & + & 3 & 1 & 0 & 2 & 0 & 0 & 0 & 0 \\
\hline Heidelberg $(n=15)$ & & & & & + & & & & 0 & 0 & 0 & 0 & 15 & 12 & 3 & 0 \\
\hline London $(n=360)$ & & + & & & & & & + & 316 & 177 & 128 & 11 & 44 & 19 & 24 & 1 \\
\hline Mbandaka $(n=7)$ & & + & & & & & & + & 7 & 4 & 3 & 0 & 0 & 0 & 0 & 0 \\
\hline Meleagridis $(n=2)$ & & + & & & & & & & 2 & 2 & 0 & 0 & 0 & 0 & 0 & 0 \\
\hline Montevidio $(n=48)$ & & + & + & & & & & + & 8 & 5 & 2 & 1 & 40 & 23 & 16 & 1 \\
\hline Muenster $(n=45)$ & & + & & & & & & + & 45 & 36 & 5 & 4 & 0 & 0 & 0 & 0 \\
\hline Newport $(n=12)$ & & & + & & & & & + & 4 & 1 & 3 & 0 & 8 & 3 & 5 & 0 \\
\hline Stanleyville $(n=1)$ & & & + & & & & & & 1 & 1 & 0 & 0 & 0 & 0 & 0 & 0 \\
\hline Typhimurium $(n=20)$ & & + & + & & & & + & & 15 & 11 & 2 & 2 & 5 & 4 & 1 & 0 \\
\hline Typhimurium 1,2 null $(n=14)^{e}$ & & & & & + & & & & 0 & 0 & 0 & 0 & 14 & 14 & 0 & 0 \\
\hline $\mathrm{ND}(n=5)^{f}$ & & & & & & & & + & 0 & 0 & 0 & 0 & 5 & 5 & 0 & 0 \\
\hline Total $(n=710)$ & + & + & + & + & + & + & + & + & 561 & 339 & 190 & 34 & 149 & 92 & 55 & 2 \\
\hline
\end{tabular}

${ }^{a}$ Values represent the number of isolates of each serovar identified. Pre, preevisceration carcasses; Final, final carcasses.

${ }^{b}$ Five veal processing plants (A through E) were visited for initial samples (1). There was a second sample collection (2) performed at three of the plants approximately 12 months later. + , collection trip serovar was identified.

${ }^{c}$ Bob veal are calves younger than 2 weeks old at harvest.

${ }^{d}$ Formula-fed veal are calves raised on milk replacer formula for 20 to 22 weeks before harvest.

${ }^{e}$ Monophasic variant of Salmonella enterica serovar Typhimurium (1,4,[5],12:i:-).

${ }^{f} \mathrm{ND}$, Salmonella serovar could not be determined.

variable and likely endemic to the various incoming sources of veal calves. Salmonella Agona was the only serovar observed at three different plants (Table 3). Salmonella Heidelberg and a monophasic variant of serovar Typhimurium $(1,4,[5], 12: i:-)$, hereafter referred to as Typhimurium 1,2 null, were only found during follow-up sample collection at the formula-fed veal plant $\mathrm{C}$. When the two sample collections are compared, Salmonella serovars Cerro, Montevideo, and Typhimurium were observed during both collections at bob veal plant B. Salmonella serovars Cerro and Typhimurium were present at enumerable concentrations on hides and carcasses at plant B and only on bob veal hides and carcasses at plant E, while they were not present at these concentrations on the formula-fed veal at plant E. Although Salmonella serovar Montevideo was present on 23 of the 48 formula-fed veal hide samples at plant $\mathrm{E}$, and at enumerable levels in two of those cases, it was only observed on bob veal hides at plant B five times over the two sample collections (Table 3). These observations suggest that particular serovars of Salmonella may be attributed to certain types of veal; however, given the limited number of samples in our study, drawing such conclusions should be weighed with caution until further research has been performed.

Susceptibility of Salmonella isolates. All the Salmonella isolates were screened for resistance to Ctx, Nal, and
Tet (data not shown). In total, 91 isolates representing 13 serovars demonstrated resistance by growing on one or more agar containing each of the antibiotics. Only Salmonella serovars Altona, Anatum, Give, and Stanleyville were absent in the resistant group. A significantly greater proportion $(P<0.05)$ of isolates from formula-fed veal $(40$ of $149,26.8 \%$ ) compared with bob veal (54 of 561, 9.6\%) grew in the presence of one or more of the antibiotics. Isolates were screened against Tet as an indicator of general AMR, as it is one of the most commonly observed resistances (40). Thirty-seven isolates (33 from bob veal and 4 from formula-fed veal) were only resistant to Tet, while the remainder were resistant to $\mathrm{Ctx}$ or $\mathrm{Nal}$ or both. The group of isolates only resistant to Tet were of seven different serovars. Similarly, in a study of grain-fed veal calves, resistance to Tet was observed to be the most common resistance alone and in combination with other antimicrobials among four reported serovars (18).

We screened for resistance to $\mathrm{Ctx}$ and $\mathrm{Nal}$ as indicators of resistance to significant human-use antibiotics $(21,40)$. This method of screening is rapid but crude. Further investigation of these isolates appearing resistant to Ctx and $\mathrm{Nal}$ through the use of MIC panels of antibiotics or molecular screening for specific genes related to the resistance is required before they can be definitively categorized. Therefore, isolates that demonstrated growth on Ctx plates or Nal plates or both can only be considered 
putatively resistant. Thirty-five isolates grew on Ctx plates, 18 grew on Nal plates, and one isolate grew on both. Salmonella serovars with isolates putatively resistant to Ctx were Agona $(n=12)$, Typhimurium 1,2 null $(n=13)$, Typhimurium $(n=7)$, and Cerro $(n=2)$. Salmonella serovars with isolates putatively resistant to Nal were Heidelberg $(n=13)$, London $(n=2)$, Typhimurium $(n=2)$, and Cerro $(n=1)$. The isolate putatively resistant to both Ctx and Nal was Salmonella serovar Typhimurium 1,2 null. The occurrence of these resistant serovars was specific to plant and veal calf production group. All of the identified Salmonella Heidelberg isolates were from formula-fed veal plants $\mathrm{C}(n=13)$ and $\mathrm{D}(n=1)$. All of the identified Salmonella Typhimurium 1,2 null isolates were found at plant $\mathrm{C}$ as well. Overall, the isolates that screened putatively resistant to significant human-use antibiotics were a greater proportion of formula-fed veal isolates $(22.1 \%)$ compared with bob veal isolates (21 of 561, 3.7\%).

The isolates of Salmonella serovars Heidelberg and Typhimurium 1,2 null are of particular interest from a public health stand point. Salmonella Heidelberg infected a total of 56 people from 15 states during an outbreak in 2015 to 2017 linked to contact with dairy calves (16). Thirty-five percent of people in this outbreak were hospitalized, and no deaths were reported. The Salmonella Heidelberg isolates in this outbreak were resistant to multiple antibiotics, including Tet and Nal (16). Serovar Typhimurium 1,2 null is a monophasic strain of Salmonella and has been reported to be of increasing concern in the European Union. A similar monophasic Salmonella serovar Typhimurium 1,2 null caused two major outbreaks, involving 133 confirmed cases, 24 hospitalizations, and one death in Luxembourg in 2006 (35). In Italy, the Salmonella serovar Typhimurium 1,2 null represented the third most frequent serovar isolated from human cases between 2004 and 2008 (17). Unlike the isolates in our study that were putatively resistant to Tet and Cef but sensitive to Nal, clinical isolates of Typhimurium 1,2 null that caused 206 illnesses in a 2013 to 2014 outbreak in central Italy were only resistant to Nal (17). In Denmark, serovar Typhimurium 1,2 null is reported to account for $20.5 \%$ of human Salmonella infections (22). Most cases were often associated with consumption of pork and poultry rather than beef or veal. The Salmonella serovar Typhimurium 1,2 null in Denmark often exhibited antibiotic resistance and is considered an important epidemic health risk (22).

The samples used in this study were originally collected to examine bacterial indicators of sanitary dressing and the efficacy of changes made to those practices (8) and were then later revisited to characterize Salmonella present on bob and formula-fed veal calf hides and its transmission to carcasses during the steps of harvest. As a result, the samples are limited in number and represent only five veal processing plants during one season of the year. Further, the numbers of bob veal to formula-fed veal are unbalanced and may not reflect the actual numbers of veal harvested. Note that the limited number of samples in our study only provide preliminary data, and larger systematic surveys of Salmonella in veal processing are needed to more fully understand this problem.

In conclusion, we visited five veal processors to assess prevalence and concentrations of Salmonella present at different stages of harvest of bob and formula-fed veal. Bob veal calves were found to have greater prevalence and concentrations of Salmonella on hides and carcasses than formula-fed veal. It is likely that the concentrations of Salmonella on hides and the challenges of hide removal from bob veal carcasses are combining to result in the increased prevalence FSIS has observed in veal. Although having less Salmonella, the formula-fed veal in our study was found to be contaminated by Salmonella serovars of a greater public health concern than those associated with bob veal. Some processors have already made changes that should improve the safety of veal, but further efforts are necessary from both bob and formula-fed veal processors.

\section{ACKNOWLEDGMENTS}

The authors thank the following: the cooperating veal processing plants for access to sample collection; the American Veal Association and its members for their contributions to this project; Greg Smith, Lawnie Luedtke, Bruce Jasch, and Frank Reno for technical support; and Jody Gallagher for secretarial assistance. Trade names are necessary to accurately report experimental results. The use of trade names by a U.S. Department of Agriculture (USDA) author implies no approval of the product to the exclusion of others that may also be suitable; further, the USDA neither guarantees nor warrants the standard of any products mentioned.

\section{REFERENCES}

1. Arthur, T. M., J. M. Bosilevac, D. M. Brichta-Harhay, M. N. Guerini, N. Kalchayanand, S. D. Shackelford, T. L. Wheeler, and M. Koohmaraie. 2007. Transportation and lairage environment effects on prevalence, numbers, and diversity of Escherichia coli O157:H7 on hides and carcasses of beef cattle at processing. J. Food Prot. 70:280-286.

2. Arthur, T. M., J. M. Bosilevac, D. M. Brichta-Harhay, N. Kalchayanand, S. D. Shackelford, T. L. Wheeler, and M. Koohmaraie. 2007. Effects of a minimal hide wash cabinet on the levels and prevalence of Escherichia coli O157:H7 and Salmonella on the hides of beef cattle at slaughter. J. Food Prot. 70:1076-1079.

3. Arthur, T. M., X. Nou, N. Kalchayanand, J. M. Bosilevac, T. Wheeler, and M. Koohmaraie. 2011. Survival of Escherichia coli O157:H7 on cattle hides. Appl. Environ. Microbiol. 77:3002-3008.

4. Bosilevac, J. M., T. M. Arthur, J. L. Bono, D. M. Brichta-Harhay, N. Kalchayanand, D. A. King, S. D. Shackelford, T. L. Wheeler, and M. Koohmaraie. 2009. Prevalence and enumeration of Escherichia coli O157:H7 and Salmonella in U.S. abattoirs that process fewer than 1000 head of cattle per day. J. Food Prot. 72:1272-1278.

5. Bosilevac, J. M., T. M. Arthur, T. L. Wheeler, S. D. Shackelford, M. Rossman, J. O. Reagan, and M. Koohmaraie. 2004. Prevalence of Escherichia coli $\mathrm{O} 157$ and levels of aerobic bacteria and Enterobacteriaceae are reduced when hides are washed and treated with cetylpyridinium chloride at a commercial beef processing plant. $J$. Food Prot. 67:646-650.

6. Bosilevac, J. M., M. N. Guerini, N. Kalchayanand, and M. Koohmaraie. 2009. Prevalence and characterization of Salmonellae in commercial ground beef in the United States. Appl. Environ. Microbiol. 75:1892-1900.

7. Bosilevac, J. M., X. Nou, M. S. Osborn, D. M. Allen, and M. Koohmaraie. 2005. Development and evaluation of an on-line hide decontamination procedure for use in a commercial beef processing plant. J. Food Prot. 68:265-272. 
8. Bosilevac, J. M., R. Wang, B. E. Luedtke, T. L. Wheeler and M. Koohmaraie. 2016. Contamination revealed by indicator microorganism levels during veal processing. J. Food Prot. 79:1341-1347.

9. Brichta-Harhay, D. M., T. M. Arthur, J. M. Bosilevac, M. N. Guerini, N. Kalchayanand, and M. Koohmaraie. 2007. Enumeration of Salmonella and Escherichia coli O157:H7 in ground beef, cattle carcass, hide and faecal samples using direct plating methods. J. Appl. Microbiol. 103:1657-1668.

10. Brichta-Harhay, D. M., T. M. Arthur, J. M. Bosilevac, N. Kalchayanand, J. W. Schmidt, R. Wang, S. D. Shackelford, G. H. Loneragan, and T. L. Wheeler. 2012. Microbiological analysis of bovine lymph nodes for the detection of Salmonella enterica. J. Food Prot. 75:854-858.

11. Brichta-Harhay, D. M., M. N. Guerini, T. M. Arthur, J. M. Bosilevac, N. Kalchayanand, S. D. Shackelford, T. L. Wheeler, and M. Koohmaraie. 2008. Salmonella and Escherichia coli O157:H7 contamination on hides and carcasses of cull cattle presented for slaughter in the United States: an evaluation of prevalence and bacterial loads by immunomagnetic separation and direct plating methods. Appl. Environ. Microbiol. 74:6289-6297.

12. Centers for Disease Control and Prevention. 2002. Outbreak of multidrug-resistant Salmonella Newport-United States, JanuaryApril 2002. Morb. Mortal. Wkly. Rep. 51:545-548.

13. Centers for Disease Control and Prevention. 2006. Multistate outbreak of Salmonella Typhimurium infections associated with eating ground beef-United States, 2004. Morb. Mortal. Wkly. Rep. 55:180-182.

14. Centers for Disease Control and Prevention. 2015. National Antimicrobial Resistance Monitoring System (NARMS) for enteric bacteria: Human isolates final report, 2013. Available at: https:// www.cdc.gov/narms/pdf/2013-annual-report-narms-508c.pdf. Accessed 31 August 2018.

15. Centers for Disease Control and Prevention. 2017. National enteric disease surveillance: Salmonella annual report, 2016. Available at: https://www.cdc.gov/nationalsurveillance/Salmonella-surveillance. html. Accessed 31 August 2018.

16. Centers for Disease Control and Prevention. 2017. Multistate outbreak of multidrug-resistant Salmonella Heidelberg infections linked to contact with dairy calves. Available at: https://www.cdc. gov/Salmonella/heidelberg-11-16/index.html. Accessed 31 August 2018.

17. Cito, F., F. Baldinelli, P. Calistri, E. Di Giannatale, G. Scavia, M. Orsini, S. Iannetti, L. Sacchini, I. Mangone, L. Candeloro, A. Conte, C. Ippoliti, D. Morelli, G. Migliorati, N. B. Barile, C. Marfoglia, S. Salucci, C. Cammà, M. Marcacci, M. Ancora, A. M. Dionisi, S. Owczartek, I. Luzzi, and the Outbreak Investigation Group. 2016. Outbreak of unusual Salmonella enterica serovar Typhimurium monophasic variant 1,4 [5],12:i:-, Italy, June 2013 to September 2014. Euro Surveill. 21(15):pii=30194.

18. Cook, A., R. J. Reid-Smith, R. J. Irwin, S. A. McEwen, V. Young, and C. Ribble. 2011. Antimicrobial resistance in Campylobacter, Salmonella, and Escherichia coli isolated from retail grain-fed veal meat from southern Ontario, Canada. J. Food Prot. 74:1245-1251.

19. Eblen, D. R., K. E. Barlo, and A. L. Naugle. 2006. U.S. Food Safety and Inspection Service testing for Salmonella in selected raw meat and poultry products in the United States, 1998 through 2003: an establishment-level analysis. J. Food Prot. 69:2600-2606.

20. Echeita, M. A., S. Herrera, J. Garaizar, and M. A. Usera. 2002. Multiplex PCR-based detection and identification of the most common Salmonella second-phase flagellar antigens. Res. Microbiol. 153:107-113.

21. Gunell, M., M. A. Webber, P. Kotilainen, A. J. Lilly, J. M. Caddick, J. Jalava, P. Huovinen, A. Siitonen, A. J. Hakanen, and L. J. Piddock. 2009. Mechanisms of resistance in nontyphoidal Salmonella enterica strains exhibiting a nonclassical quinolone resistance phenotype. Antimicrob. Agents Chemother. 53:3832-3826.

22. Gymoese, P., G. Sørensen, E. Litrup, J. E. Olsen, E. M. Nielsen, and M. Torpdahl. 2017. Investigation of outbreaks of Salmonella enterica serovar Typhimurium and its monophasic variants using wholegenome sequencing, Denmark. Emerg. Infect. Dis. 23:1631-1639.
23. Hanson, D. L., G. H. Loneragan, T. R. Brown, D. J. Nisbet, M. E. Hume, and T. S. Edrington. 2016. Evidence supporting vertical transmission of Salmonella in dairy cattle. Epidemiol. Infect. 144:962-967.

24. Heithoff, D. M., W. R. Shimp, J. K. House, Y. Xie, B. C. Weimer, R. L. Sinsheimer, and M. J. Mahan. 2012. Intraspecies variation in the emergence of hyperinfectious bacterial strains in nature. PLoS Pathog. 8:e1002647.

25. Helsel, D. R. 2012. Statistics for censored environmental data using Minitab and R, 2nd ed. Wiley, Hoboken, NJ.

26. Herrera-León, S., J. R. McQuiston, M. A. Usera, P. I. Fields, J. Garaizar, and M. A. Echeita. 2004. Multiplex PCR for distinguishing the most common phase-1 flagellar antigens of Salmonella spp. J. Clin. Microbiol. 42:2581-2586.

27. Herrera-León, S., R. Ramiro, M. Arroyo, R. Díez, M. A. Usera, and M. A. Echeita. 2007. Blind comparison of traditional serotyping with three multiplex PCRs for the identification of Salmonella serotypes. Res. Microbiol. 158:122-127.

28. House, J. K., M. M. Ontiveros, N. M. Blackmer, E. L. Dueger, J. B. Fitchhorn, G. R. McArthur, and B. P. Smith. 2001. Evaluation of an autogenous Salmonella bacterin and a modified live Salmonella serotype Choleraesuis vaccine on a commercial dairy farm. Am. J. Vet. Res. 62:1897-1902.

29. Johnston, J., A. Adnan Aydin, J. M. Bosilevac, G. Acuff, P. Bronstein, J. Luchansky, and P. Evans. 2013. Microbial and chemical hazards in veal: identification of contributing factors, data gaps and solutions. Presented at the International Association of Food Protection 2013 Annual Meeting, Charlotte, NC, 29 to 31 July 2013.

30. Kallings, L. O., A. B. Laurell, and B. Zetterberg. 1959. An outbreak due to Salmonella Typhimurium in veal with special reference to phage and fermentation typing. Acta Pathol. Microbiol. Scand. 45:347-356.

31. Kim, S., B. K. Lee, Y. H. Kang, H. J. Nam, O. Y. Lim, W. S. Seok, and J. K. Park. 2003. A virulent strain of Salmonella enterica serovar London isolated in infants with enteritis traced by active surveillance and molecular epidemiological study. J. Korean Med. Sci. 18:325330 .

32. Laufer, A. S., J. Grass, K. Holt, J. M. Whichard, P. M. Griffin, and L. H. Gould. 2015. Outbreaks of Salmonella infections attributed to beef-United States, 1973-2011. Epidemiol. Infect. 143:2003-2013.

33. Luedtke, B. E., and J. M. Bosilevac. 2015. Comparison of methods for the enumeration of enterohemorrhagic Escherichia coli from veal hides and carcasses. Front. Microbiol. 6:1062.

34. McDonough, P. L., S. J. Shin, and D. H. Lein. 2000. Diagnostic and public health dilemma of lactose-fermenting Salmonella enterica serotype Typhimurium in cattle in the northeastern United States. $J$. Clin. Microbiol. 38:1221-1226.

35. Mossong, J., P. Marques, C. Ragimbeau, P. Huberty-Krau, S. Losch, G. Meyer, G. Moris, C. Strottner, W. Rabsch, and F. Schneider. 2007. Outbreaks of monophasic Salmonella enterica serovar 4,[5],12:i:- in Luxembourg, 2006. Euro Surveill. 12(6):pii=719.

36. Nazer, A. H., and O. D. Osborne. 1976. Salmonella infection and contamination of veal calves: a slaughterhouse survey. Br. Vet. J. 132:192-201.

37. Nou, X., M. Rivera-Betancourt, J. M. Bosilevac, T. L. Wheeler, S. D. Shackelford, B. L. Gwartney, J. O. Reagan, and M. Koohmaraie. 2003. Effect of chemical dehairing on the prevalence of Escherichia coli O157:H7 and the levels of aerobic bacteria and Enterobacteriaceae on carcasses in a commercial beef processing plant. J. Food Prot. 66:2005-2009.

38. Park, J. K., W. S. Seok, B. J. Choi, H. M. Kim, B. K. Lim, S. S. Yoon, S. Kim, Y. S. Kim, and J. Y. Park. 2004. Salmonella enterica serovar London infections associated with consumption of infant formula. Yonsei Med. J. 45:43-48.

39. Scallan, E., R. M. Hoekstra, F. J. Angulo, R. V. Tauxe, M. A. Widdowson, S. L. Roy, J. L. Jones, and P. M. Griffin. 2011. Foodborne illness acquired in the United States-major pathogens. Emerg. Infect. Dis. 17:7-15.

40. Schmidt, J. W., G. E. Agga, J. M. Bosilevac, D. M. Brichta-Harhay, S. D. Shackelford, R. Wang, T. L. Wheeler, and T. M. Arthur. 2015. 
Occurrence of antimicrobial-resistant Escherichia coli and Salmonella enterica in the beef cattle production and processing continuum. Appl. Environ. Microbiol. 81:713-725.

41. Stefan, G. 1997. Food safety issues affecting the dairy beef industry. J. Dairy Sci. 80:3458-3462.

42. Travers, K., and M. Barza. 2002. Morbidity of infections caused by antimicrobial-resistant bacteria. Clin. Infect. Dis. 34:S131-S134.

43. U.S. Department of Agriculture, Food Safety and Inspection Service. 2011. Report on the Food Safety and Inspection Service's microbiological and residue sampling programs. Available at: www.fsis.usda.gov/wps/wcm/connect/0816b926-c7ee-4c24-922234ac674ec047/FSIS_Sampling_Programs. Accessed 31 August 2018.

44. U.S. Department of Agriculture, Food Safety and Inspection Service. 2013. Food safety information-Veal from farm to table. Available at: https://www.fsis.usda.gov/wps/portal/fsis/topics/food-safetyeducation/get-answers/food-safety-fact-sheets/meat-preparation/ veal-from-farm-to-table/CT_Index. Accessed 31 August 2018.

45. U.S. Department of Agriculture, Food Safety and Inspection Service. 2013. Increased verification by inspection program personnel of sanitary dressing at veal slaughter establishments. FSIS Notice 2013. Available at: https://www.fsis.usda.gov/wps/portal/fsis/topics/ regulations/fsis-notices. Accessed 31 August 2018

46. U.S. Department of Agriculture, Food Safety and Inspection Service. 2015. Nationwide Beef and Veal Carcass Microbiological Baseline
Survey Report. Available at: https://www.fsis.usda.gov/wps/portal/ fsis/topics/data-collection-and-reports/microbiology/baseline/ baseline. Accessed 31 August 2018.

47. U.S. Department of Agriculture, Food Safety and Inspection Service. 2016. Constituent update-July 2, 2015. Available at: http://www fsis.usda.gov/wps/portal/fsis/newsroom/meetings/newsletters/ constituent-updates/archive/2015/ConstUpdate070215. Accessed 31 August 2018.

48. Varma, J. K., K. Molbak, T. J. Barrett, J. L. Beebe, T. F. Jones, T. Rabatsky-Ehr, K. E. Smith, D. J. Vugia, H. G. Chang, and F. J. Angulo. 2005. Antimicrobial-resistant nontyphoidal Salmonella is associated with excess bloodstream infections and hospitalizations. $J$. Infect. Dis. 191:554-561.

49. Wang, R., M. Koohmaraie, B. E. Luedtke, T. L. Wheeler, and J. M. Bosilevac. 2014. Effects of in-plant interventions on reduction of enterohemorrhagic Escherichia coli and background indicator microorganisms on veal calf hides. J. Food Prot. 77:745-751.

50. Wang, R. F., W. W. Cao, and C. E. Cerniglia. 1997. A universal protocol for PCR detection of 13 species of foodborne pathogens in foods. J. Appl. Microbiol. 83:727-736.

51. Wong, T. L., C. Nicol, R. Cook, and S. MacDiarmid. 2007. Salmonella in uncooked retail meats in New Zealand. J. Food Prot. 70:1360-1365. 